\title{
Measuring Training Effectiveness: A Case Study Of Public Sector Project Management In Pakistan
}

Atiq Ur Rehman, PIFRA, Department of Auditor General of Pakistan, Pakistan Azhar Mansur Khan, Business Management Consultants, Pakistan

Rashid Ahmed Khan, National University of Modern Languages, Pakistan

\begin{abstract}
Many organizations do invest precious resources on training and development but without examining how training interventions could effectively contribute in the achievement of organizational objectives, eventually resources are wasted. To yield desired level of performance, it is an imperative that organizations effectively plan, implement and evaluate their training interventions. Several authors have studied the training and development practices but most the studies lack any operational framework for diagnosing the training and development system. This study used Kunder's (1998) indicators of training ineffectiveness and developed a framework for measuring effectiveness of training and diagnosing problems at various stages of training and development. We developed a questionnaire based on framework and collected data from 115 project directors to measure training effectiveness in project organizations in Pakistan. The study had found that on overall basis training practices are ineffective. Results reveal that there is a poor mechanism of evaluation of training and use of evaluation results. The framework developed by this study can be used in other organizations to measure training effectiveness and diagnose problems at various stages of training cycle.
\end{abstract}

Keywords: Training and development; effectiveness of training; training

\section{INTRODUCTION}

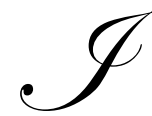

n Pakistan civil servants are mainly responsible for implementing the projects and programmes (Siddiqi, 2005, p. 3). But their performance has deteriorated over time owing to several factors: the most prominent among them being the inadequate capabilities (Planning Commission, 2001, p. 263; United Nations, 2005, pp. 50-51; ADB, 2002, p. 23; 2003, p. 10; and 2004 and the World Bank, 1999, p. 11). Thus, lack of capacity badly hits the performance of the development interventions i.e. projects, impeding the process of development. This phenomenon is more or less a global in nature. In the recent years, it has received a worldwide attention. Paris Declaration on Aid Effectiveness of 2005 came into effect as a recognition to the problem. Pakistan is also one of 91 participating countries of the Declaration.

The Paris Declaration has strongly emphasized upon the need of capacity building to improve effectiveness of the development interventions. Need for capacity building and continuous improvement has tremendous support from the literature. Literature suggests that continuous development of human factor is crucial for yielding higher level of performance in organizations (Natsios, 2005, p. 5; Jacobson, Rubin \& Selden, 2002, p. 486; Lakhani, 2003, p. 63; Barbeito, 2004, p. 102; and Nelson \& Economy, 2005, p. 93). Irony is that many organizations, even in developing countries, do invest precious resources on training and development but without examining how training interventions could effectively contribute in the achievement of organizational objectives, eventually resources are wasted (Raj, 2005, p. 7.1). Public sector organizations are no exception to such problem. Rather, these organizations are often criticized for lack of accountability towards investment in training and development. The issue of training governance is even of greater importance for the developing countries like Pakistan where resources for 
development are scarce and capacity for planning and implementation is limited.

In order to guide the training interventions to yield the desired outcomes, it is an imperative that organizations effectively plan, implement and evaluate their training interventions. But this is not a straightforward issue to manage. Ineffectiveness may breed at any stage starting from need identification to evaluation. Question arises, how can we diagnose problems at any stage and how can we measure effectiveness of training? Several authors (Saari, Johnson, McLaughlin and Zimmerle, 1988; Abdalla and Homoud, 1995; Kunder, 1998) have studied the training and development practices. For example, Saari, Johnson, McLaughlin and Zimmerle (1988) conducted a survey of management training and education practices in the USA. And Abdalla and Homoud (1995) conducted a survey of management training and development practices in the State of Kuwait. But these studies have covered only some selected dimensions of training and development practices and lack any operational framework for diagnosing the training and development system. Other researchers like Kunder (1998, pp. 2-4) did identify indicators of ineffective training and development systems. However, such studied did not suggest any diagnostic model for measuring the degree of ineffectiveness.

This paper attempts to bridge up the gap in literature by proposing a diagnostic model for measuring degree of effectiveness of training interventions. Research questions which guided this study are:

1. What are the indicators of effectiveness of training practices?

2. How can we diagnose problems in the training practices?

\section{LITERATURE REVIEW}

\section{Need for capacity building}

Literature accords tremendous need of training of the public managers, as they have often been criticised for their bureaucratic, and impersonal and reactive attitude. Cong and Pandya (2003) view the knowledge as a critical factor of competitiveness in the public sector. And a well-trained civil service is an imperative for sustainable development (Mahmood, 2001, p. 40). So, there is a great need of their training to accomplish upgraded roles and responsibilities (Petridou \& Spathis, 2000). Moreover, continuing education is needed also to avert obsolescence in the public sector organizations (Greenhaus, Challan, \& Godshalh, 2000, p. 230). Hence training infrastructure of a government is an important predictor of its performance (Jacobson, Rubin \& Selden, 2002, p. 485).

Project Management is an important and very specialized area of training in the public sector, as it is directly related with performance of the development interventions. Mahmood (2001) terms the Project Management as one of the weakest areas in the public sector of Pakistan and stresses on the need for continuous training of the public sector employees (p. 220). Need for enhancement of the capacity of public sector in the area of project management is growing owing to the increasing volume of development expenditure. Development expenditure in Pakistan gradually rose from 2.4 percent of GDP in the year 1999-2000 to 4.2 percent in 2005-06 (Government of Pakistan, 2006, p. 69).

Importance of training and development in Pakistan has grown phenomenally, as civil service in Pakistan suffers from inadequate skills, low salary and deficient incentives, politicization, poor morale, and lack of internal or external accountability. These factors have resulted in ineffective delivery of public services in the country (World Bank, 2001).

Several studies have highlighted the need of capacity building and training in project management system in Pakistan. World Bank (2006, p. 7) and Japan International Cooperation Agency [JICA] (2003) have emphasized upon the need for strengthening the project implementation capacity in Pakistan. While recognizing this problem in Pakistan, International Development Center of Japan [IDCJ] (2004, p. 11) has highlighted the need for strengthening institutional implementation capacity so as to avoid any failure like that of Social Action Programme (SAP). SAP projects (SAP-I commenced in 1994 and SAP-II in 1998, each with cost of US\$ 250 Million) are examples of the worst failures in the country (World Bank, 2006, pp. 16-18). Sahibzada and Mahmood (1992) have also stressed on 
the need of up-gradation of human skills of the public sector managers in Pakistan. They report that most of the government officials have never attended training, while others need refresher courses. It is evident that high rate of projects failure in Pakistan is associated with weak implementation capacity of the project organizations. Development of human capital in project organizations is imperative to improve the implementation capacity in a bid to reduce the incidence of project failure in the country.

\section{Measurement of Training Effectiveness}

Only provision of training may not address the issue, but systematic management of training is also required to ensure effectiveness of the capacity development interventions for achieving the desired developmental goals. Therefore, need for more effective training practices increases. Need for accountability of education and training programmes in both public and private sectors has increased since early 1970s (Auchey, 2000, p. 166).

Several authors have studied the training and development practices. Some authors like Abdalla and Homoud (1995) used stage-wise approach for studying the training and development practices. Abdalla and Homoud (1995) conducted a survey of management training and development practices in the State of Kuwait. The questionnaire consisted of four main parts covering training needs assessment, programmes and participant selection, programme evaluation and future trends.

Second stream of studies have devised and used issue-wise approach of studying training and development practices. For example, Mead, Tobin and Couturiaux (1996) used a framework consisting of five components: 1) introduction; 2) staff development; 3) training process; 4) measurement; and planning and requirements. Another study conducted on this pattern is that carried out by Tregaskis and Dany (1996, p. 26). They used a framework consisting of following six broad areas: 1) organizational commitment to training (finance and days training per occupational group per year); 2) training programmes conducted; 3) methods adopted for training needs evaluation; 4) methods used to evaluate the effectiveness of training; 5) career development systems (formal career plans or annual career development interviews) and 6) integration of training with HR system (workforce planning, training new employees).

In a study on evaluation of training, Kunder (1998, pp. 2-4) identified six indicators of ineffective training and development systems: 1) lack of top management support for the training and development system; 2) no clear link between training and organizational goals or plans; 3) inadequate, or incorrect accounting of the costs of training; 4) limited or inadequate training needs assessment; 5) lack of support for applying new skills and knowledge on the job; and lack of meaningful evaluation of training. One of the basic limitations of these studies is that it is hard to use their frameworks as diagnostic tools for measuring effectiveness training effectiveness.

\section{RESEARCH METHODOLOGY}

This study employed a blend of descriptive and exploratory research methods to achieve its stated goal. The work of Kunder (1998) guided in the development of conceptual framework and construction of questionnaire. Initially we prepared a checklist in the light of indicators of training ineffectiveness identified by Kunder (1998), which include 1) top management support for the training and development system; 2) clarity of link between training and organizational goals or plans; 3) adequate, correct accounting of the costs of training; 4) TNA; 5) support for applying skills and knowledge learned in training on the job; and 6) assessment of impact of training on project performance. These indicators (we treated these indicators as constructs) needed to be further operationalized. We interviewed 20 project managers / directors to identify variables to measure these indicators. Variables are listed in Table 1. Based on these variables we developed a questionnaire and used it on full scale basis after pre-testing.

Before operationalizing Kunder's indicators, we added one more indicator i.e. use of evaluation results. We believe that if training evaluation is done but results are not used, training management system will still likely to remain ineffective. To operationalize the indicator of "lack of meaningful evaluation of training", we used 4-stage model developed by Kirkpatrick (1994). The four stages of learning transfer include reaction, learning, transfer and result. 
Table 1. Framework for Assessing Ineffectiveness of Training

\begin{tabular}{ll}
\hline \multicolumn{1}{c}{ Indicator } & \multicolumn{1}{c}{ Indicators used in this study to measure effectiveness } \\
\hline $\begin{array}{l}\text { Lack of top management support for the training } \\
\text { and development system }\end{array}$ & $\begin{array}{l}\text { Budgetary provision, utilization of training budget, attitude of top } \\
\text { management towards training, how often employees are relieved for training, } \\
\text { percent of employees with access to Internet, efforts of organization in } \\
\text { exploring training opportunities, perceived impact of training } \\
\text { Alignment of training with job functions, alignment of training with career } \\
\text { development, use of evaluation results, integration of training into HRM } \\
\text { plans, selection of courses on need basis, selection of participants on need } \\
\text { basis, level of HR Information System }\end{array}$ \\
$\begin{array}{ll}\text { Accounting system in Government of Pakistan } \\
\text { Inadequate, or incorrect accounting of the costs } \\
\text { of training }\end{array}$ & $\begin{array}{l}\text { Frequency of Training Needs Assessment (TNA) } \\
\text { Limited or inadequate training needs assessment }\end{array}$ \\
$\begin{array}{l}\text { Lack of support for applying new skills and } \\
\text { knowledge on the job }\end{array}$ & $\begin{array}{l}\text { sharing and assessment whether learning is being applied } \\
\text { Reaction to training } \\
\text { Ask of meaningful evaluation of training } \\
\text { Application of learning on the job }\end{array}$ \\
& $\begin{array}{l}\text { Assess impact of training on project performance } \\
\text { Practice of documenting lessons learnt } \\
\text { Use of evaluation results }\end{array}$ \\
\hline
\end{tabular}

The approach discussed above aimed at managing the construct validity and pre-testing helped in ensuring face validity of the survey instrument.

Population of the study consisted of 1503 public sector projects included in the PSDP 2005-06. A sample of 200 projects was considered appropriate for this study. We distributed the sample size among all three sectors of economy which include social sector (SS), infrastructure sector (IS) and other sectors (OS). The Government of Pakistan uses this nomenclature (Planning Commission, 2005). Sub-sectors like health, education, and population are the subjects of SS. Roads, railway, buildings, and information technology come under IS. And sub-sectors such as agriculture, livestock, fisheries, forestry, industry, and mining are grouped in PS. While distributing sample among three sectors, we assigned 50 percent weight to the number of projects included in the sector's portfolio and remaining 50 percent to the total amount of financial allocations in the sector. Based on the sample size estimated in Table 2 we randomly selected the projects from the PSDP. Respondents of this study were the project directors / managers because we believed that they are the most potential source of required of information. After two weeks of mailing the questionnaires, we did a follow up exercise to expedite the response. In response we received back 141 questionnaires, out of which only 115 were found fit for analysis. So response rate for this study is 71 percent and effective response rate 65 percent. This sampling strategy helped in managing external validity issues. We analyzed the data in Statistical Package for Social Scientists (SPSS).

Table 2. Category-wise Details on Projects and Distribution of Sample

\begin{tabular}{lccccc}
\hline & \multicolumn{2}{c}{ Allocation 2005-06 } & Projects & \multicolumn{2}{c}{ Sample size } \\
\cline { 2 - 6 } Category & (Rs. & & & & \\
& Million) & Percent share & No. & Percent share & No. of projects \\
\hline Infrastructure & $92,246.20$ & 45.22 & 195 & 12.97 & 58 \\
Social Development & $73,112.40$ & 35.84 & 626 & 41.65 & 78 \\
Others & $38,641.50$ & 18.94 & 682 & 45.38 & 64 \\
Total & $204,000.10$ & 100.00 & 1,503 & 100.00 & 200 \\
\hline
\end{tabular}

Source: Planning Commission (2005) 


\section{RESULTS AND DISCUSSIONS}

\section{Lack of top management support for training and development system}

One of the major reasons of the failure of development interventions is the unsupportive top management (Nicholas, 1990; Rothwell, 2005, p. 6). Several other others have also highlighted importance of the management support in the success of learning interventions (OAGBC, 1999; Skule, 2004). There is strong relationship between commitment and support of the top management and the effectiveness of a training programme (Huang, 2001). Question arises, how can we measure degree of support? Results of interview method reveal that support of top management for training and development reflects in a number of forms like budgetary provision for training, utilization percentage of training budget, perceived attitude of top management towards training of employees, efforts of the organization in exploring training opportunities for employees, and perceived benefits of training. Besides, it is also important to note that when training opportunity is at hand, it is not guaranteed that the concerned employee would be relieved for training. If senior management accords higher priority to training then it is likely that the employees would be relieved for training and vice versa. We used these seven indicators in this study to measure the mean score for first indicator for ineffective training and development that is 'lack of top management support for the training and development system'. The indicators are detailed in Table 1.

Results indicate that overall mean score is close to just satisfactory level that is 3.29 . Ideally, it should have been close to 5.00. Therefore, support of top management towards training and development of employees needs improvement. Sector wise analysis indicates that in none of the cases, support was in levels of good-to-excellent. However, IS (3.41) showed slightly better score than OS (3.32) and SS (3.18) (Table 3).

These findings support the results of this study conducted by Haque et al. (2006, p. 9) which found that 30 percent of the middle level civil servants and 33 percent of the senior level civil servants did never receive any formal or on the job training.

Table 3. Indicators for Lack of Top Management Support for the Training and Development System

\begin{tabular}{|c|c|c|c|c|c|}
\hline Indicators used in this study & Unit & $\begin{array}{l}\text { Social } \\
\text { Sector }\end{array}$ & $\begin{array}{l}\text { Infrastructure } \\
\text { Sector }\end{array}$ & $\begin{array}{l}\text { Other } \\
\text { Sector }\end{array}$ & Overall \\
\hline \multirow[t]{2}{*}{ Budgetary provision } & MS5* & 2.86 & 3.21 & 3.00 & 3.01 \\
\hline & $\mathrm{SD}^{* *}$ & 1.322 & 1.053 & 1.185 & 1.203 \\
\hline \multirow[t]{2}{*}{ Utilization of training budget } & MS5 & 2.66 & 3.00 & 2.74 & 2.78 \\
\hline & SD & 1.200 & 1.414 & 1.349 & 1.310 \\
\hline \multirow[t]{2}{*}{ Attitude of top management towards training } & MS5 & 3.59 & 3.79 & 3.63 & 3.66 \\
\hline & SD & 0.972 & 0.650 & 0.751 & 0.815 \\
\hline \multirow[t]{2}{*}{ How often employees are relieved for training } & MS5 & 3.64 & 3.79 & 3.87 & 3.76 \\
\hline & SD & 0.892 & 0.857 & 0.777 & 0.844 \\
\hline \multirow{2}{*}{ Percent of employees with access to Internet } & MS5 & 2.91 & 2.94 & 3.16 & 3.00 \\
\hline & SD & 1.030 & 1.116 & 1.285 & 1.139 \\
\hline \multirow{2}{*}{ Efforts of organization in exploring training opportunities } & MS5 & 2.77 & 3.15 & 3.00 & 2.96 \\
\hline & SD & 1.075 & 0.939 & 0.986 & 1.012 \\
\hline \multirow[t]{2}{*}{ Perceived impact of training (Cumulative) } & MS5 & 3.81 & 3.97 & 3.82 & 3.86 \\
\hline & $\mathrm{SD}$ & 0.814 & 0.518 & 0.685 & 0.695 \\
\hline Combined mean & MS5 & 3.18 & 3.41 & 3.32 & 3.29 \\
\hline
\end{tabular}

$*$ MS5 = Mean score on scale of 5.00; SD = Standard Deviation

\section{No clear link between training and organizational goals or plans}

Second indicator of ineffective training and development systems is 'No clear link between training and organizational goals or plans'. It was measured with the help of seven indicators that is alignment of training with job functions, alignment of training with career development, how often results of evaluation are further used?, integration of training into HRM plans, selection of courses on need basis, selection of participants on need basis and Level of HR Information System. We included an indicator of alignment between training and the career 
development (personal goals) for the reason that it is source of intrinsic motivation. In organizations where only organizational goals are taken care off and personal goals are compromised, it is highly likely that training interventions would prove to be less effective.

Mean score of seven indicators (2.97) indicates that on overall basis, situation of linkage between training and organization goals or plans is below satisfactory. Sector-wise analysis suggests that OS (3.01) was slightly better than IS (2.98) and the SS (2.93) (Table 4). Results of One-way ANOVA suggest that sectors do not significantly differ on account of alignment of training with career development $(F[2,109]=0.475, p=.623)$ and alignment of training with job functions $(\mathrm{F}[2,109]=1.338, \mathrm{p}=.267)$.

Table 4. Indicators for Non-Clarity of Link between Training and Organizational Goals or Plans

\begin{tabular}{|c|c|c|c|c|c|}
\hline Indicators used in this study & Unit & $\begin{array}{l}\text { Social } \\
\text { Sector }\end{array}$ & $\begin{array}{l}\text { Infrastructure } \\
\text { Sector }\end{array}$ & Other Sector & Overall \\
\hline \multirow[t]{2}{*}{ Alignment of training with job functions } & MS5* & 3.02 & 3.24 & 3.34 & 3.19 \\
\hline & $\mathrm{SD}^{* *}$ & 1.045 & 0.708 & 0.938 & 0.926 \\
\hline \multirow{2}{*}{ Alignment of training with career development } & MS5 & 3.23 & 3.09 & 3.05 & 3.13 \\
\hline & $\mathrm{SD}$ & 1.008 & 0.879 & 0.837 & 0.913 \\
\hline \multirow{2}{*}{$\begin{array}{l}\text { How often results of evaluation are further } \\
\text { used? }\end{array}$} & MS5 & 2.27 & 2.46 & 2.16 & 2.30 \\
\hline & $\mathrm{SD}$ & 1.202 & 1.141 & 0.850 & 1.061 \\
\hline \multirow[t]{2}{*}{ Integration of training into HRM plans } & MS5 & 2.36 & 2.67 & 2.68 & 2.56 \\
\hline & $\mathrm{SD}$ & 1.102 & 0.924 & 0.989 & 1.019 \\
\hline \multirow[t]{2}{*}{ Selection of courses on need basis } & MS5 & 3.50 & 3.24 & 3.74 & 3.50 \\
\hline & $\mathrm{SD}$ & 1.110 & 0.936 & 0.760 & 0.968 \\
\hline \multirow[t]{2}{*}{ Selection of participants on need basis } & MS5 & 3.45 & 3.39 & 3.39 & 3.42 \\
\hline & $\mathrm{SD}$ & 1.150 & 0.933 & 0.887 & 1.000 \\
\hline \multirow[t]{2}{*}{ Level of HR Information System } & MS5 & 2.66 & 2.79 & 2.68 & 2.70 \\
\hline & $\mathrm{SD}$ & 0.939 & 0.893 & 0.775 & 0.868 \\
\hline Combined mean & MS5 & 2.93 & 2.98 & 3.01 & 2.97 \\
\hline
\end{tabular}

* MS5 = Mean score on scale of 5.00; SD** = Standard Deviation

\section{Inadequate or incorrect accounting of the costs of training}

Public sector of Pakistan is having a well defined accounting system that is based on International Public Sector Accounting Standards (IPSAS). However, it is not accurate system for measuring the cost of training. Cost of training generally includes three components that is, tuition fee, cost of travelling boarding and lodging, and cost of absence of the trainee from the job during the period of training.

In public sector (in Pakistan), accounting of tuition fee is often very difficult as in most of the cases, public sector training institutions do not charge any tuition fee to the participants from the public sector. Even when training is outsources, payment is made from a head "Payment to Others". It is a general head and does not differentiate training from some other expenditures like payment for consultancies etc. Estimation of the second component of the cost of training that is travelling, boarding and lodging is also a difficult task as the code for any kind of travelling, boarding and lodging (Travelling Allowance and the Daily Allowance) is the same. They are not sensitive to the purpose of travelling. Moreover, in case project vehicle is used for travelling purpose, cost to be incurred on the travelling of participant to and from the training venue is never maintained separately. In some cases, travelling facility is also provided by the training institutions. Moreover, in most of the cases, trainings are funded by external agencies, so accounting of training cost in that situation becomes even more difficult. Third component of training cost is even harder for accounting.

\section{Limited or inadequate training needs assessment}

TNA is another important indicator of the effectiveness of training. Overall score of only frequency of TNA exercises was found to be just 2.17 on a scale of 5 (where $1=$ never, $5=$ regular feature). Score is not satisfactory. Therefore, this indicator also reflects the state of ineffectiveness of training and development. (Table 5) 
Table 5. Indictor for Limited or Inadequate Training Needs Assessment

\begin{tabular}{lcc}
\hline & Sector & Cumulative Score on scale of 5 on the practices of Training Need Assessment \\
\hline Social & 1.93 \\
Infrastructure & 2.39 \\
Other & 2.24 \\
Overall & 2.17 \\
\hline
\end{tabular}

\section{Lack of support for applying new skills and knowledge on the job}

Fifth indicator of ineffective training and development is 'lack of support for applying skills and knowledge learned in training on the job'. To measure this indicator, five proxy indicators were used: 1) culture of sharing information, 2) group meetings, 3) post-training reflections, 4) e-sharing, and 5) assessment whether learning is being applied.

Combined mean value of just 2.36 suggests that it is below the satisfactory level. In all sectors, combined mean was found to be well below 3 which implies that in none of the sectors, situation is satisfactory (Table 6).

Table 6. Indicators for Lack of Support for Applying Skills and Knowledge Learned in Training on the Job

\begin{tabular}{|c|c|c|c|c|c|}
\hline Indicators used in this study & Unit & $\begin{array}{l}\text { Social } \\
\text { Sector }\end{array}$ & $\begin{array}{l}\text { Infrastructure } \\
\text { Sector }\end{array}$ & $\begin{array}{l}\text { Other } \\
\text { Sector }\end{array}$ & Overall \\
\hline \multirow[t]{2}{*}{ Culture of information sharing } & MS5* & 3.02 & 3.06 & 2.84 & 2.97 \\
\hline & $\mathrm{SD}^{* *}$ & 1.110 & 1.171 & 1.001 & 1.088 \\
\hline \multirow[t]{2}{*}{ Group meetings } & MS5 & 3.18 & 2.70 & 2.79 & 2.91 \\
\hline & MS5 & 1.435 & 1.262 & 1.255 & 1.335 \\
\hline \multirow[t]{2}{*}{ Post-training reflections or presentations } & SD & 2.59 & 2.58 & 2.61 & 2.59 \\
\hline & MS5 & 1.604 & 1.347 & 1.366 & 1.444 \\
\hline \multirow[t]{2}{*}{ E-sharing } & SD & 2.27 & 1.94 & 2.03 & 2.10 \\
\hline & MS5 & 1.353 & 1.223 & 1.219 & 1.270 \\
\hline \multirow[t]{2}{*}{ Assess whether learning is being applied } & SD & 1.11 & 1.39 & 1.16 & 1.21 \\
\hline & MS5 & 0.321 & 0.747 & 0.547 & 0.554 \\
\hline Combined mean & SD & 2.43 & 2.33 & 2.29 & 2.36 \\
\hline
\end{tabular}

* MS5 = Mean score on scale of 5.00; SD** = Standard Deviation

\section{Lack of meaningful evaluation of training}

Sixth indicator for ineffective training and development is 'lack of meaningful evaluation of training'. An evaluation is meaningful if it measures impact of training on project performance. Results indicate that no one respondent reported existence of this practice in any project (Table 7).

Table 7. Indicator for Lack of Meaningful Evaluation of Training

\begin{tabular}{|c|c|c|c|c|c|}
\hline Indicators used in this study & Unit & $\begin{array}{l}\text { Social } \\
\text { Sector }\end{array}$ & $\begin{array}{c}\text { Infrastructure } \\
\text { Sector }\end{array}$ & $\begin{array}{l}\text { Other } \\
\text { Sector }\end{array}$ & Overall \\
\hline \multirow[t]{2}{*}{ Reaction to training } & MS5 & 1.98 & 2.39 & 2.11 & 2.14 \\
\hline & SD & 1.171 & 1.197 & 1.085 & 1.154 \\
\hline \multirow[t]{2}{*}{ Ask trainees to make presentations } & MS5 & 1.00 & 1.00 & 1.00 & 1.00 \\
\hline & SD & 0.618 & 1.053 & 0.889 & 0.867 \\
\hline \multirow[t]{2}{*}{ Assess whether learning is being applied } & MS5 & 1.11 & 1.39 & 1.16 & 1.21 \\
\hline & SD & 0.321 & 0.747 & 0.547 & 0.554 \\
\hline \multirow[t]{2}{*}{ Assess impact of training on performance } & MS5 & 1.00 & 1.00 & 1.00 & 1.00 \\
\hline & SD & 0.00 & 0.00 & 0.00 & 0.00 \\
\hline Overall & MS5 & 1.27 & 1.45 & 1.32 & 1.34 \\
\hline
\end{tabular}




\section{Use of evaluation results}

Only evaluation is not sufficient, it is also important that whether evaluation results are being used. The results reveal that practice of the use of evaluation results is not in practice. However, informal practices may exist in some organizations.

Table 8. Use of Evaluation Results

\begin{tabular}{|l|c|c|c|c|c|}
\hline Indicators used in this study & Unit & Social Sector & $\begin{array}{c}\text { Infrastructure } \\
\text { Sector }\end{array}$ & Other Sector & Overall \\
\hline Practice of documenting lesson learnt & MS5 & 1.00 & 1.00 & 1.00 & 1.00 \\
\cline { 2 - 6 } & SD & 0.00 & 0.00 & 0.00 & 0.00 \\
\hline Use of evaluation results & MS5 & 1.00 & 1.00 & 1.00 & 1.00 \\
\cline { 2 - 6 } & MS5 & 0.00 & 0.00 & 0.00 & 0.00 \\
\hline
\end{tabular}

\section{CONCLUSION}

Current training practices in the public sector project management system in Pakistan are not effective (Table 9). Moreover, there is no significant difference in the effectiveness score among all three sectors. Results reveal that public sector project organizations in Pakistan are having several problems in the management of training and development practices. There is no mechanism for adequate and appropriate costing of training courses. Eventually, no one knows how much resources have been invested on any employee. There are individuals (mostly generalists) who avail training courses costing millions of rupees while yet there is another group of employees (mostly technical) in the government who retire without getting any single training. There are clear evidences for adverse impact.

Table 9. Cumulative Score on Effectiveness of Training

\begin{tabular}{|c|c|c|c|c|}
\hline \multirow[b]{2}{*}{ Indicators used in this study } & \multicolumn{4}{|c|}{ Cumulative Score on scale of 5} \\
\hline & Social Sector & $\begin{array}{l}\text { Infrastructure } \\
\text { Sector }\end{array}$ & $\begin{array}{l}\text { Other } \\
\text { Sector }\end{array}$ & Overall \\
\hline $\begin{array}{l}\text { Top management support for the training and development } \\
\text { system }\end{array}$ & 3.18 & 3.41 & 3.32 & 3.29 \\
\hline $\begin{array}{l}\text { Clarity of link between training and organizational goals or } \\
\text { plans }\end{array}$ & 2.93 & 2.98 & 3.01 & 2.97 \\
\hline Adequate, correct accounting of the costs of training & 1.00 & 1.00 & 1.00 & 1.00 \\
\hline TNA & 1.93 & 2.39 & 2.24 & 2.17 \\
\hline $\begin{array}{l}\text { Support for applying skills and knowledge learned in training } \\
\text { on the job }\end{array}$ & 2.43 & 2.33 & 2.29 & 2.36 \\
\hline Meaningful evaluation & 1.27 & 1.45 & 1.32 & 1.34 \\
\hline Use of evaluation results & 1.00 & 1.00 & 1.00 & 1.00 \\
\hline Mean of the mean scores & 1.96 & 2.08 & 2.03 & 2.02 \\
\hline
\end{tabular}

Second and third most neglected areas are the lack of meaningful evaluation of training courses and use of evaluation results for improvement in the effectiveness of training practices. This is quite obvious. If need for a meaningful evaluation is not recognized, how come, one can talk about use of evaluation results. And fourth problem area lies in the poor culture of TNA. Perhaps root cause of all these problems is the supremacy of generalists in the project organizations.

Findings of this study lead to the conclusion that there exists a dire need to bring radical change in the training and development system in the public sector in Pakistan, which is in line with the suggestion of United Nations (2005, p. 28). Regular HRD audit exercises could offer a solution to the problem. The framework developed by this study can be used by the organizations to measure and monitor training effectiveness and diagnose problems at various stages of training cycle. Though this model has been tested in the public sector but it can also be used in the private sector business entities. 


\section{AUTHOR INFORMATION}

Atiq ur Rehman is currently working with PIFRA, Department of Auditor General of Pakistan, Islamabad, Pakistan, as Training (Consultant). He was scholar at National University of Modern Languages, Islamabad, Pakistan. He has served Planning Commission, Government of Pakistan for eight years.

Dr. Azhar Mansur Khan is visiting Professor at NUML and is Principal Consultant and Regional Director Pakistan, for Business Management Consultants. Dr. Khan is also the CEO of the Institute of Project Management and Emotional Intelligence in Paksitan. Besides, he is an adjunct professor at ESC Lille France, USQ Australia, CASE, NUST, PIQC and PPMI. Dr. Khan's background incorporates 30 years of experience that includes senior leadership positions in the UN, government, industry and NGOs. He has designed and facilitated over 300 training courses in Pakistan and several other countries.

Dr. Rashid Ahmed Khan is Dean at NUML. He has served the Government of Pakistan for more than 25 years. He has taught in several universities and has supervised several PhD students. He has authored several research articles published nationally and internationally.

\section{REFERENCES}

1. Abdalla, I.A., \& Homoud, M.A. (1995) 'A survey of management training and development practices in the State of Kuwait', Journal of Management Development, 14, 1, 14-25.

2. Asian Development Bank (ADB). (2002, May 21) Pakistan: Country Strategy Paper (CSP) 2002-2006. Retrieved December 29, 2004, from http://ec.europa.eu/comm/external_relations/pakistan/csp/02_06_en.pdf

3. ADB. (2003, August) Pakistan Economic Update (July 2002 - June 2003). Retrieved October 18, 2004, from http://adb.org/documents/economic_updates/pak/eco_update_pak05.pdf

4. ADB. (2004, September). Country Strategy and Program Update - 2005-2006: Pakistan. Report No. PAK 2004-17. Retrieved October 25, 2005, from http://www.adb.org/Documents/CSPs/PAK/2004/CSP-PAK2004.pdf

5. Auchey, G. J. (2000). An evaluation model for project management training programmes. In the ASC $36^{\text {th }}$ Annual Conference, Purdue University, West Lafayette, Indiana, March 29 - April 1, 2000, (pp. 164-174). Retrieved November, 13, 2004, from http://asceditor.unl.edu/archives/2000/auchey00.htm

6. Barbeito, C. L. (2004) Human resource policies and procedures for non-profit organizations (New Jersey: John Wiley \& Sons, Inc).

7. Cong, X., \& Pandya, K.V. (2003, December). Issues of knowledge management in the public sector. Electronic Journal of Knowledge Management, 1(2), 25-32. Retrieved February 15, 2006, from http://www.ejkm.com/volume-1/volume1-issue-2/issue-2-art-3-cong-pandya.pdf

8. Government of Pakistan. (2006) Pakistan economic survey 2005-06 (Islamabad, Economic Advisor's Wing, Finance Division).

9. Greenhaus, J. H., Challan, G. A. \& Godshalh, V. M. (2000) Career development ( ${ }^{\text {rd }}$ ed.) (Fort Worth, USA, Marcourt College Publishers).

10. International Development Center of Japan (IDCJ). (2004, March). Country Assistance Evaluation of Pakistan: Summary. Retrieved October 18, 2005, from http://www.mofa.go.jp/policy/oda/evaluation/2003/pakistan.pdf

11. Jacobson, W, Rubin, E.V., \& Selden, S.C. (2002, Winter). 'Examining training in large municipalities: linking individual and organizational training needs', Public Personnel Management, 31, 4, 485-505.

12. Japan International Cooperation Agency (JICA). (2003). Country study for Japan's Official Development Assistance to the Islamic Republic of Pakistan - Development toward a sustainable society: Medium and long term perspectives. Tokyo: Institute for International Cooperation, JICA.

13. Kirkpatrick, D.L. (1994) Evaluating training programs (San Francisco, Berrett-Koehler).

14. Kunder, L. H. (1998). Employees' perception of the status and effectiveness of the training and development system and of the value of training and development. Unpublished PhD Dissertation in Education, Virginia Polytechnic Institute and State University, USA. 
15. Lakhani, M. K. (2003, December). Civil service training in Pakistan: Search for the new paradigm. The Journal (National Institute of Public Administration, Karachi), 8(4).

16. Mahmood, S. (2001) The Musharaf regime and the governance crisis: A case study of the Government of Pakistan (Huntington, USA, Nova Science Publishers, Inc).

17. Mead, N., Tobin, L., \& Couturiaux, S. (1996). Best training practices within the software engineering industry. Technical Report No. CMU/SEI-96-TR-034, ESC-TR-96-134. Pittsburgh: Software Engineering Institute, Carnegie Mellon University. January 28, 2006, from http://www.sei.cmu.edu/pub/documents/96.reports/pdf/tr034.96.pdf

18. Natsios, A. S. (2005, Autumn). The nine principles of reconstruction and development. Parameters - the US Army War College Quarterly, XXXV, pp. 4-20. Retrieved December 8, 2006, from http://carlislewww.army.mil/usawc/Parameters/05autumn/natsios.pdf

19. Nelson, B., \& Economy, P. (2005) The management bible (New Jersey, John Wiley \& Sons, Inc).

20. Petridou, E.N., \& Spathis, T.S. (2000). Designing training interventions: human or technical skills training? International Journal of Training and Development, 5(3), 185-195.

21. Planning Commission (2001) Ten Year Perspective Development Plan 2001-11 and Three Year Development Programme 2001-04 (Islamabad: Government of Pakistan).

22. Planning Commission. (2005, June) Public Sector Development Programme 2005-06, (Islamabad, Government of Pakistan).

23. Raj, A. (2005) Training theory and practice (Ludhiana, Kalyani Publishers).

24. Saari, L. M., Johnson, T. R., McLaughlin, S. D., \& Zimmerle, D. M. (1988) 'A survey of management training and education practices in U.S. companies', Personnel Psychology, 41, 731-743.

25. Sahibzada, S.A., \& Mahmood, M.A. (1992) 'Why most development projects fail in Pakistan? A plausible explanation' The Pakistan Development Review, 31,4, (Part-I), 1111-1122.

26. Siddiqi, M.S.A. (2005). The new public management and civil service reform in Pakistan: The case of recruitment and promotion practices. Unpublished master thesis in Governance and Development Management, University of Birmingham, Birmingham, UK. Retrieved December 8, 2006, from http://www.idd.bham.ac.uk/research/dissertations/2004-2005/PDF/siddiqi.pdf

27. United Nations. (2005). Human resources for effective public administration in a globalized world. Report No. ST/ESA/PAD/SER.E/65, ST/ESA/PAD/SER.E/65, United Nations Department of Economic and Social Affairs Division for Public Administration and Development Management. Retrieved November 13, 2006, from http://unpan1.un.org/intradoc/groups/public/documents/UN/UNPAN021329.pdf

28. World Bank. (1999). 1998 Annual Review of Development Effectiveness. Washington, D.C.: OED, the World Bank. Retrieved October 18, 2004, from http://www.worldbank.org/html/oed/ardefm98.htm

29. World Bank. (2001, March). Pakistan's reform programme: Progress and prospects report. Retrieved January 25, 2004, from http://lnweb18.worldbank.org/sar/sa.nsf/083c4661ad49652f852567d7005d85b8/c3e79a8d2720625385256a 090074d943? OpenDocument

30. World Bank. (2006). Pakistan: An evaluation of the World Bank's assistance. Washington: IEG, the World Bank. Retrieved December 8, 2006, from http://lnweb18.worldbank.org/OED/OEDDocLib.nsf/DocUNIDViewForJavaSearch/88F4238DA5D117688 $\underline{5257122006 \mathrm{C} 11 \mathrm{DC} / \text { \$file/pakistan_cae.pdf }}$ 